\title{
Impacts of fire and phosphorus on sawgrass and cattails in an altered landscape of the Florida Everglades
}

Yegang $\mathrm{Wu}^{3^{*}}$, Ken Rutchey ${ }^{1}$, Susan Newman ${ }^{1}$, Shili Miao ${ }^{1}$, Naiming Wang ${ }^{1}$, Fred $\mathrm{H} \mathrm{Sklar}^{1}$ and William H Orem²

\begin{abstract}
Introduction: Although fire as a critical ecological process shapes the Florida Everglades landscape, researchers lack landscape-based approach for fire management. The interactive effect of fire, nutrients, water depth, and invasive cattails (Typha spp.) on vegetation communities is of special concern for ecosystem restoration. In particular, questions concerning the effect of fire on nutrient release and, by extension, the potential thereof to stimulate sawgrass (Cladium jamaicense Crantz) re-growth and cattail expansion under varying hydrological conditions are of immediate relevance to ecologists and land managers who work to restore the Everglades.

Methods: In late April of 1999, a 42,875 ha surface fire, including a 100 ha peat fire, burned the northern section of Water Conservation Area 3A (WCA-3A) in the Everglades. In this study, total phosphorus (TP) in soil, surface water, pore-water, and vegetation was sampled at non-burned, surface-burned and peat-burned areas within one and five months after the burn. Four years after the initial fire, field data were collected in a large scale survey to analyze how the 1999 fire affected cattail distribution in the altered landscape of high soil TP and cattail habitats. Existing GIS maps were utilized to select field sampling locations and to provide additional information for the analysis.

Results: The analyses showed that five months after the fire, sawgrass biomass re-growth was about 5 times higher in burned areas $\left(611 \pm 47 \mathrm{~g} / \mathrm{m}^{2}\right)$ than in non-burned areas $\left(102 \pm 18 \mathrm{~g} / \mathrm{m}^{2}\right)$. Sawgrass re-growth in water depths less than $30 \mathrm{~cm}$ was $4.9 \pm 0.4 \mathrm{~g} / \mathrm{m}^{2} /$ day while sawgrass re-growth in water depths deeper than $60 \mathrm{~cm}$ decreased to $0.5 \pm 0.3 \mathrm{~g} / \mathrm{m}^{2} /$ day. Cattail biomass re-growth in peat-burned areas was as high as $1,079 \pm 38 \mathrm{~g} / \mathrm{m}^{2}$. The data also showed that post-fire cattail expansion could be related to cattail stands existing before the fire. Furthermore, post-fire cattail appeared more significant expansion in the areas with soil TP above $900 \mathrm{mg} / \mathrm{kg}$ than in that with soil TP below $900 \mathrm{mg} / \mathrm{kg}$.

Conclusions: The data showed that fire within altered landscapes (e.g. high soil TP and/or cattail) of the Everglades could stimulate the re-growth and expansion of cattails, and post-fire re-growth of sawgrass could be severely impeded by deep water after a surface-burn. This research indicates that fire continues to be an effective ecological process for maintaining the Everglades; therefore, ecologists and land managers may have to reevaluate the future management of natural fire with regard to its dynamic relationship with high soil TP and cattail expansion in the altered Everglades landscape.
\end{abstract}

Keywords: Fire, Phosphorus, Sawgrass, Cattails, Everglades, Water depth, Altered landscape, Wetlands

\footnotetext{
* Correspondence: ywu_mail@yahoo.com

${ }^{3}$ Cardno ENTRIX, 339 Whitecrest Drive, Maryville, TN 37801, USA

Full list of author information is available at the end of the article
} 


\section{Introduction}

Fire is recognized as a key historical factor in shaping the Florida Everglades landscape and is being considered now as one of the management tools appropriate for the Everglades restoration (Slocum et al. 2003, Wu et al. 1996, Wade et al. 1980). Before the construction of the approximately 2,000 km of canals and levees in the Everglades for drainage and flood protection, fire occurred systematically and helped facilitate the maintenance of the ridge and slough landscape with dotted tree islands (Beckage et al. 2009; Ogden 2005; Wu et al. 2002). Fires ignited by summer lightning storms burned sawgrass ridges until they hit natural barriers such as sloughs or tree islands or until they were extinguished by summer rains. Fires ignited by rare winter lightning strikes could burn larger areas due to dry conditions that typically persist during that season. The pattern of ridge, slough, and tree islands in the Everglades ensured that fires would burn and leave a mosaic of burned and non-burned vegetation in the landscape (Gunderson and Snyder 1994). This burned and non-burned mosaic provided the diversity of habitats and refuges for native plants and wildlife (Childers et al. 2006, Wu et al. 2002, Vogl 1973).

The Everglades ecosystems flourished and evolved uninterruptedly until the middle of the nineteenth century. The construction of canal and levees in and adjacent to the Everglades, which redirected water and compartmentalized the landscape, then began disrupting the natural processes. This compartmentalization and water management activities altered the hydroperiod and produced a gradient of drier to wetter conditions from north to south, respectively, in each of the constructed impoundments. As a result, fire regimes changed greatly as natural or human-induced fires increased in frequency and intensity in the northern areas of the impoundments; however, the spatial extent of fire in the Everglades was often restricted by the canal/levee system and also by other landscape features such as airboat trails (Smith and Newman 2001, Wu et al. 1996, Gunderson 1994). Water management (diversion) further aggravated the situation by creating drier dry seasons and wetter wet seasons, which ultimately altered fire frequency and intensity. Large expanses of cattail invasion have also changed the fire regime (in both fire frequency and fire intensity) dramatically (Beckage 2005, Wu et al. 1996). Soil oxidation occurring in the northern sections of the impoundments have caused the ridge and slough pattern to lose its micro-topology and transition to a sawgrass/brush community with less slough. As a result the landscape has become more homogeneous (Wu et al. 2006, Beckage and Platt 2003) with fires now consuming even larger uniform areas of the landscape. Many ecologists believe that fire is a critical metric for restoring and maintaining the altered Everglades and that it must be incorporated as part of a long-term maintenance regime (Hagerthey et al. 2008, Lockwood et al. 2003, Wu et al 1997, Gunderson 1994).

Fire intensity and frequency under different fuel loadings and environmental conditions is of interest to ecologists and landscape managers (Gilliam and Platt 2006, Herndon et al. 1991). It has been hypothesized that water depth and fire metrics are some of the key factors influencing vegetation communities in the Everglades. Newman et al. (1998) and Wu et al. (1997) conducted research from these metrics and concluded that the combination of water depth and fire shape or alter the sawgrass (Cladium jamaicense) community and/or potentially stimulate the expansion of cattails (Typha spp.) in the Everglades landscape.

Intensive fires under the current altered system have increased the likelihood of severe peat fires, which damage sensitive resources like tree islands by burning away precious soil that in many cases took decades to centuries to form. This phenomenon was rare in the preimpoundment Everglades. In late April of 1999, a fire consumed almost the entire north section of Water Conservation Area 3A (WCA-3A) (Figure 1a), a total of 42,875 hectares. Most of the fire was categorized as surface fire, which only burned the aboveground vegetation. However, in the northwest corner of WCA-3A, approximately 100 ha of peat burns were observed. Wu et al. (1996) reported that average and largest fire sizes for WCA-2A (Figure 1a) during 1980 to 1991 were 3,505 ha and 15,390 ha, respectively. Although these quantities of ha are for a different impoundment (WCA-2A) of the Everglades, they show that the April, 1999 fire in the northern WCA-3A impoundment was an unusually large fire that consumed much more of the landscape. This large fire itself may have been the result of the altered hydrological regime and spatial mosaic of vegetation, topography and landscape patterns, which therefore changed the fire patterns and consequently the landscape patterns (Young et al. 2011, Bruland et al. 2007, Scheidt and Kalla 2007, Wu et al. 2002, Arabas 2000).

Research efforts have suggested that fire alters not just the landscape patterns but also the physical and chemical properties of organic and mineral reserves and the microbial population of soil (Gu et al. 2008, Ilstedt et al. 2006, Rashid 1987). The effects of fire on the nutrients of an ecosystem depend on the type and frequency of fire, fuel load, time and season of burn, nature of the plant tissues burnt, topography, succession status of the community, and post-fire climatic and biotic conditions (Anderson 2006, Certini 2005, Wu et al. 1996). A fire of mild intensity may stimulate high seedling establishment and growth by raising the soil temperature and nutrient status by removing plant litter and vegetation cover (Beckage and Platt 2003, Wade et al. 1980). As a result, the 


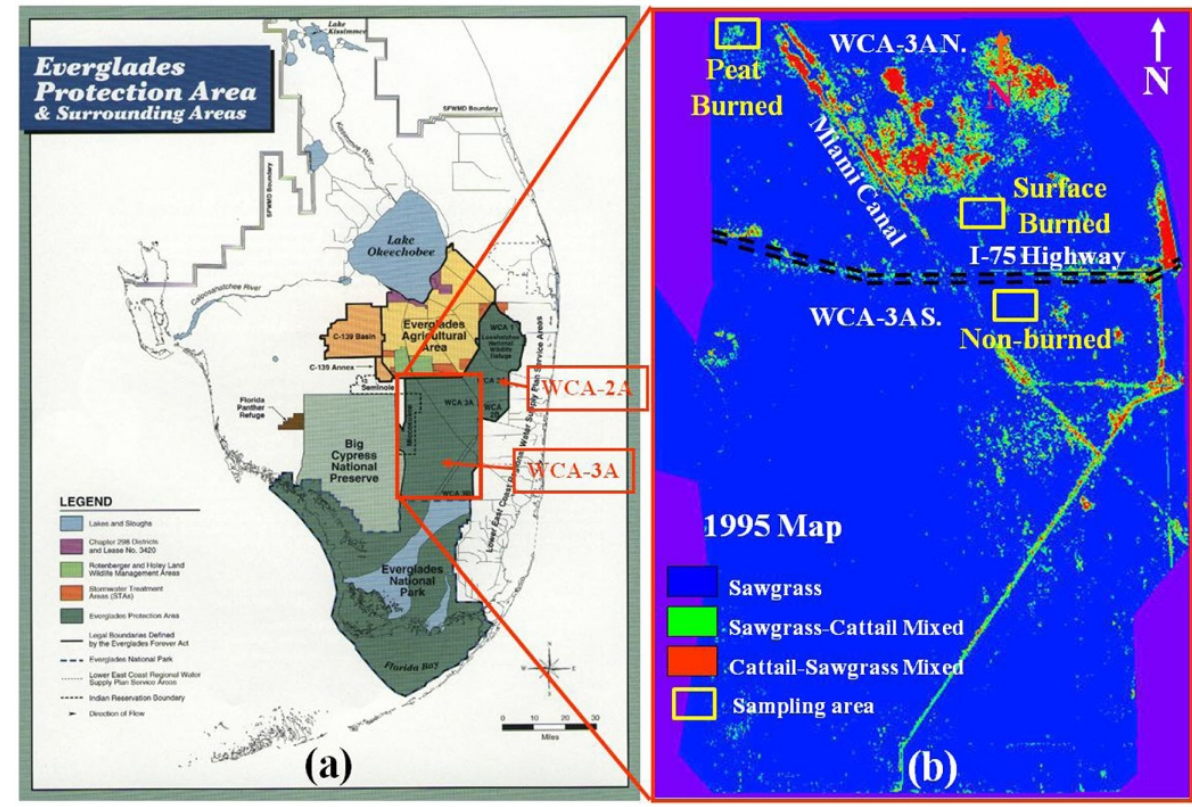

Figure 1 (a) Locations of Water Conservation Area 3A and Water Conservation Area 2A; (b) Water Conservation Area 3A north (WCA-3A N, most of the area was burned by 1999 fire) and south (WCA-3A S, not burned by 1999 fire), the peat-burned, surfaceburned and non-burned sampling areas, and the distribution of three vegetation types of sawgrass, sawgrass-cattail mixed (cattails $<50 \%$ ) and cattail-sawgrass mixed (cattails $>50 \%$ ).

nutrients for plant uptake can increase in availability or be volatilized and lost from the site, especially with the alternations in soil total phosphorus (TP) in the Everglades (Miao et al. 2010, Smith et al. 2001, DeBusk et al. 2001).

Marsh fire burns have been reported to occur at least once every 9 years within the Everglades (Hagerthey et al. 2008, Imbert and Delbé 2006, Wu et al. 1996). Fire not only gives plant communities a mechanism by which to remove decaying vegetation but also allows for new robust plant growth that did not exist prior to the burn. This robust plant growth following a fire has been a stable metric within the Everglades, which cycles the variety and availability of food sources necessary for much of the wildlife (Bruland et al. 2007, Scheidt and Kalla 2007).

Newman et al. (1997) reported that over-drainage of peat soils may lead to soil compaction and phosphorus nutrient accumulation. Agricultural runoff and urban development have also caused elevated point source loadings of phosphorus into the Everglades (Adorisio et al. 2006; Davis 1994). These phosphorus loadings have over time resulted in elevated soil $\mathrm{P}$ concentrations, which are considered a primary factor accelerating cattail growth over sawgrass and influencing cattail invasion and distribution in the Everglades (Beckage et al. 2005, Miao and Debusk 1999, Rutchey and Vilchek 1999, Doren et al. 1997, Newman et al. 1996, Davis 1991). The issue regarding how fire and water depth interact and affect nutrient release and, in particular, how this then stimulates sawgrass re-growth and cattail expansion within nutrient impacted areas has become an important restoration consideration for ecologists and land managers (Hagerthey et al. 2008, Scheidt and Kalla 2007, Bruland et al. 2007, Ross et al. 2006, Lockwood et al. 2003, Arabas 2000, Herndon et al. 1991).

With the altered system now containing areas of increased soil TP and with the subsequent invasion of cattails, the impacts of fire within these areas require evaluation. The objective of this current research is to investigate how the 1999 northern WCA-3A fire affected phosphorus releases and, consequently, how this may have had an influence on the landscape dynamics for this area. In particular, the study's focus is post-fire sawgrass and cattail change due to fire related phosphorus releases from vegetation and/or soil. This study utilizes a natural landscape fire to measure the effects of soil nutrient release and post-fire water quality on vegetation growth and pattern. Drought with soil oxidation followed by increased water depth and duration of flooding has been shown to significantly impact cattail expansion (Newman et al. 1998, Wu et al. 1997). This study will explore this idea further by analyzing the synergistic effects of fire on cattail invasion, which will help develop an appropriate management plan for the restoration of the 
altered Everglades ecosystem. The hypotheses in this study could be set as follows:

(1) Soil, pore-water and surface-water TP may vary in peat-burned, surface-burned and non-burned areas.

(2) TP and total nitrogen (TN) in sawgrass and cattails may vary in peat-burned, surface-burned and non-burned areas.

(3) Post-fire growth and biomass of sawgrass and cattails may vary in peat-burned, surface-burned and non-burned areas.

(4) An altered landscape in terms of higher soil TP and cattail density could impact post-fire cattail expansion.

\section{Methods}

\section{Study area}

The study was conducted in the northern sections of Water Conservation Area 3A (WCA-3A), which is separated by Interstate Highway I-75 with WCA-3A North in the north and WCA-3A South in the south. Both WCA-3A North and WCA-3A South are covered primarily with sawgrass and cattails (Rutchey et al. 2005). Unlike WCA-3A South, which was not burned by the 1999 fire, WCA-3A North was burned mostly by a surface fire with about 100 ha peat burned in the northwest corner (Figure 1b). High soil TP patches (> $700 \mathrm{mg} / \mathrm{kg}$ ) are distributed along the northern portions of the Miami Canal, in the very northwest, and in the east central portions of the impoundment (Figure 2) based on a soil TP map by Reddy et al. (1994). From late April to early May of 1999, a 42,875 ha fire consumed almost the entire north section of WCA-3A. Field surveys conducted during the period of the 1999 fire found that there was very little surface water in the area and that most of the fires that occurred were surface-burns, which only burned the aboveground vegetation. The fire burned a mosaic pattern in which non-burned areas were patches of tree islands, alligator holes and wet prairies. It was evident that the micro topography played an important role in the patchiness and patterns of vegetation, fuel, and fire. In the northwest corner of WCA-3A, approximately 100 ha of peat-burned patches varied from several square meters to 200 square meters. Many of the peat fires were associated with woody vegetation or tree islands, since peat surrounding these communities tends to be at higher elevation and thus thicker and drier. Peat fires burned out all the organic materials, and casual observations indicated that the burn lowered the elevation by several inches to a foot.

\section{Sampling methods}

Spatially explicit data sampling and analyses have increased substantially and become important means for fire study in the past 20 years (Nelson 2012, Wu et al. 1996). In our study, existing GIS maps were utilized to select field sampling locations and to provide additional information for the analysis. A complete GIS vegetation

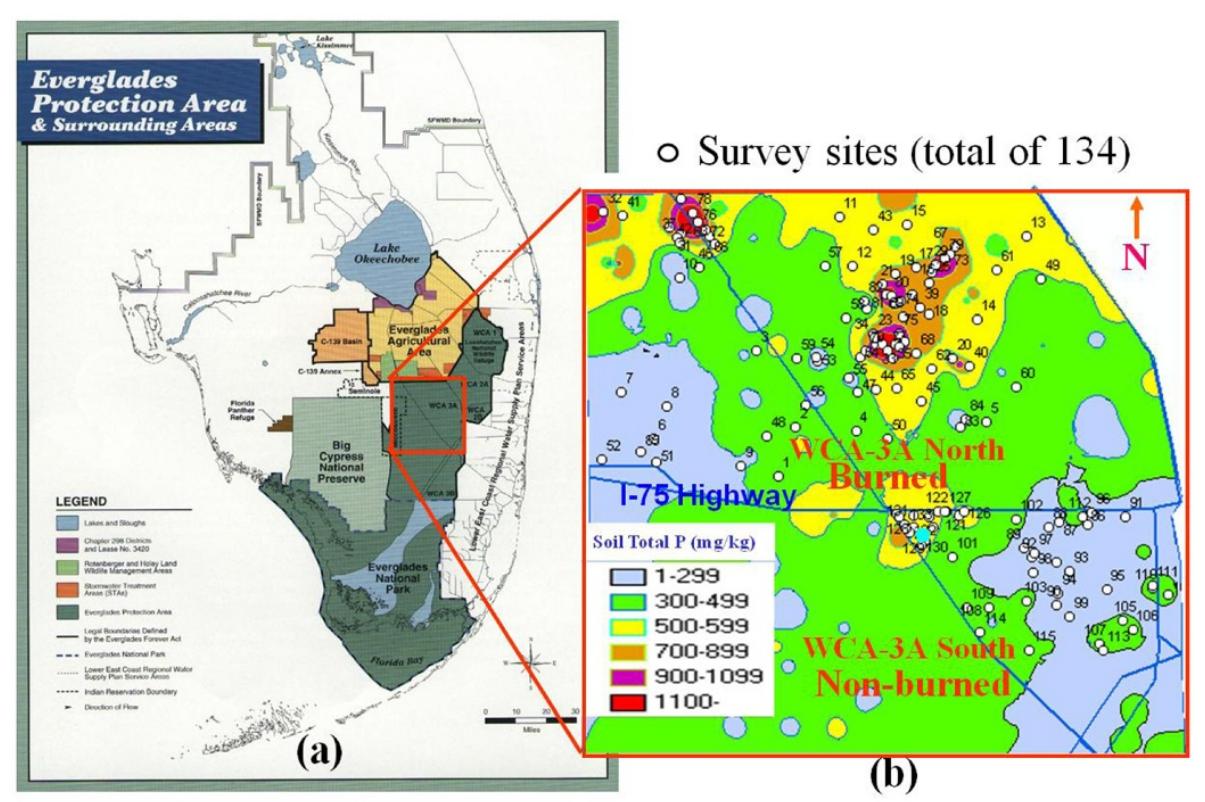

Figure 2 (a) Water Conservation Area 3A north (WCA-3A N) and north part of Water Conservation Area 3A south (WCA-3A S); (b) the soil total phosphorus map by Reddy et al. (1994) and the distribution of 134 survey sites (in circle) in six categories of soil total phosphorus $(\mathrm{mg} / \mathrm{kg}$ ) and three vegetation types of sawgrass, sawgrass-cattail mixed (cattails $<50 \%$ ) and cattail-sawgrass mixed (cattails $>50 \%$ ) in both the burned (WCA-3A N) and the non-burned (WCA-3A S) areas. 
database of WCA-3 was obtained from the WCA-3 Vegetation Map, which utilized 1:24000 scale color infrared aerial photographs and coded vegetation communities using a single hierarchal classification system by Rutchey et al. (2005). Sawgrass and wet prairie communities accounted for the greatest area (205,564 ha) and percentage $(87.5 \%)$ of polygons categorized for the entire project. Cattail habitat encompassed $5 \%$ of the project area or 11,751 ha.

A GIS map of soil TP distribution (Figure 2) was obtained from field survey data of 1992 by Reddy et al. (1994). The GIS map of soil TP was classified into six categories of (1) 0-299, (2) 300-499, (3) 500-699, (4) 700-899, (5) 900-1099 and (6) >= $1100 \mathrm{mg} / \mathrm{kg}$.

In this study, samples of soil, surface water, pore-water, and vegetation were collected from three sampling sites such as (1) non-burned $\left(26^{\circ} 07^{\prime} 04.5^{\prime \prime} \mathrm{N}\right.$ latitude, $80^{\circ}$ $34^{\prime} 04.4^{\prime \prime W}$ longitude), (2) surface burned $\left(26^{\circ} 11^{\prime} 13.3^{\prime \prime} \mathrm{N}\right.$ latitude, $80^{\circ} 44^{\prime} 25.3^{\prime \prime} \mathrm{W}$ longitude) and (3) peat burned $\left(26^{\circ} 19^{\prime} 17.7^{\prime \prime} \mathrm{N}\right.$ latitude, $80^{\circ} 47^{\prime} 43.1^{\prime \prime} \mathrm{W}$ longitude) located within WCA-3A north (Figure 1b). Three replicates were made in each site on June 1, 1999 (about one month after the fire). Soil samples were collected using a thin-walled $10 \mathrm{~cm}$ diameter $\mathrm{Al}$ coring tube to a depth of $10 \mathrm{~cm}$ and were sent to lab for nutrient analysis (e.g. TP concentration). Airstones connected to Tygon tubing were inserted $10-15 \mathrm{~cm}$ below the soil surface for porewater sampling. Monoject $140 \mathrm{cc}$ syringes were used to collect at least $80 \mathrm{ml}$ of porewater sample, which was immediately placed in an ice filled cooler and sent to lab for analysis. Surface water samples were collected at each porewater sampling location. Three replicate samples of post fire sawgrass and cattail were randomly collected from 1 x $1 \mathrm{~m}$ quadrats in non-burned, surfaceburned and peat burned locations on June 1 and October 5, 1999. Number of leaf shoots, leaf heights and surface water depth $(<30 \mathrm{~cm}$ and $>60 \mathrm{~cm})$ were recorded for each quadrat. In peat-burned areas, various cattail leaves were harvested from the new growth in the peatburned patches, and sawgrass collected at the edge of peat-burned patches since there was no sawgrass in the peat-burned patches. Leaf materials from the $1 \mathrm{x} 1 \mathrm{~m}$ quadrats were then harvested and weighed and then oven-dried at $70-75^{\circ} \mathrm{C}$ (Dash and Frith 2011) and weighed for dry-weight data. Leaf nutrient content (TN and TP) and total dry biomass were measured and analyzed.

In May 2003, four years after the initial fire, a largescale field survey was conducted over the burned and non-burned areas to analyze how the 1999 fire affected cattail distribution in the altered landscape in terms of both high soil TP and cattail invasion. A total of 134 sampling sites were selected from overlaying three GIS maps of (1) fire map, (2) vegetation map and (3) soil TP map. The fire map includes two categories of surfaceburned (WCA-3A North) and non-burned (WCA-3A South) areas (Figure 1b). A vegetation map from Rutchey et al. (2005) contains three vegetation types (Figure 1b) such as (1) sawgrass, (2) sawgrass-cattail mix (cattails $<50 \%$ ) and (3) cattail-sawgrass mix (cattails $>50 \%$ ). Soil TP map (Figure 2) from Reddy et al. (1994) classified soil TP into six categories of (1) 0-299, (2) 300-499, (3) 500-699, (4) 700-899, (5) 900-1099 and (6) >= $1100 \mathrm{mg} / \mathrm{kg}$ ). The 134 sampling sites were distributed in 2 categories of burned and non-burned, 3 categories of vegetation types and 6 categories of soil TP. For the survey, the percentage of existing sawgrass and cattail were recorded at each sampled site. A comparison of cattail distribution before and after the fire was analyzed using t-test (Alder and Roessler 1972).

\section{Results}

Results showed that post fire TP values measured on June 1, 1999 within soil, surface water and porewater samples were different in non-burned, surface-burned and peat-burned areas (Table 1). TP values were

Table $1 \mathrm{t}$-Test for the soil total phosphorus (STP, mg/kg), surface water total phosphorus (SWP, $\mu \mathrm{g} / \mathrm{L}$ ), pore-water total phosphorus (PWP, $\mu \mathrm{g} / \mathrm{L}$ ) after 1999 fire in peat-burned area (PBA), surface-burned area (SBA), non-burned area (NBA), sampling on the day of June 1, 1999 (JUN)

\begin{tabular}{|c|c|c|c|c|c|c|c|c|}
\hline$X$ & Mean (s.d.) & $\mathbf{n}$ & $\Sigma(\mathrm{X}-\mathrm{M})^{2}$ & $Y$ & Mean (s.d.) & n & $\Sigma(\mathrm{Y}-\mathrm{M})^{2}$ & $t$ \\
\hline JUN-NBA-STP & $398(123)$ & 3 & 30421 & JUN-SBA-STP & $580(49)$ & 3 & 4835 & -2.37 \\
\hline JUN-SBA-STP & $580(49)$ & 3 & 4835 & JUN-PBA-STP & $853(36)$ & 3 & 2581 & $-7.78^{*}$ \\
\hline JUN-PBA-STP & $853(36)$ & 3 & 36303 & JUN-NBA-STP & $398(123)$ & 3 & 30421 & $6.14^{*}$ \\
\hline JUN-NBA-SWP & $18(4)$ & 3 & 25 & JUN-SBA-SWP & $22(5)$ & 3 & 43 & -1.28 \\
\hline JUN-SBA-SWP & $22(5)$ & 3 & 43 & JUN-PBA-SWP & $52(16)$ & 3 & 522 & $-3.08^{*}$ \\
\hline JUN-PBA-SWP & $52(16)$ & 3 & 522 & JUN-NBA-SWP & $18(4)$ & 3 & 25 & $3.57^{*}$ \\
\hline JUN-NBA-PWP & $20(2)$ & 3 & 9 & JUN-SBA-PWP & $23(2)$ & 3 & 7 & -2.20 \\
\hline JUN-SBA-PWP & $23(2)$ & 3 & 7 & JUN-PBA-PWP & $181(9)$ & 3 & 170 & $-28.96^{*}$ \\
\hline JUN-PBA-PWP & $181(9)$ & 3 & 170 & JUN-NBA-PWP & $20(2)$ & 3 & 9 & $29.51^{*}$ \\
\hline
\end{tabular}

* Statistically significant. 
Table 2 t-Test of vegetation TP and TN in peat-burned area (PBA), surface-burned area (SBA), non-burned area (NBA) after 1999 fire for sawgrass total phosphorus (SVP, mg/kg), cattail total phosphorus (CVP, $\mathrm{mg} / \mathrm{kg}$ ), sawgrass total nitrogen (SVN, $\mathrm{mg} / \mathrm{kg})$, cattail total nitrogen (CVN, $\mathrm{mg} / \mathrm{kg})$, cattail biomass (CBM, $\left.\mathrm{g} / \mathrm{m}^{2}\right)$, and sawgrass biomass (SBM, $\left.\mathrm{g} / \mathrm{m}^{2}\right)$, sampling on the day of June 1, 1999 (JUN) and October 5, 1999 (OCT)

\begin{tabular}{|c|c|c|c|c|c|c|c|c|}
\hline $\mathrm{x}$ & Mean (s.d.) & $\mathbf{n}$ & $\Sigma(\mathrm{X}-\mathrm{M})^{2}$ & $\mathrm{Y}$ & Mean (s.d.) & $\mathbf{n}$ & $\Sigma(\mathrm{Y}-\mathrm{M})^{2}$ & $\mathbf{t}$ \\
\hline JUN-NBA-SVP & $344(47)$ & 3 & 4376 & JUN-SBA-SVP & $674(56)$ & 3 & 9231 & $-8.19^{*}$ \\
\hline JUN-SBA-SVP & $689(56)$ & 3 & 6301 & JUN-PBA-SVP & $935(70)$ & 3 & 9715 & $-4.75^{*}$ \\
\hline JUN-PBA-SVP & $935(70)$ & 3 & 9715 & JUN-NBA-SVP & $344(47)$ & 3 & 4376 & $12.19^{*}$ \\
\hline JUN-NBA-SVN & 7668 (267) & 3 & 142617 & JUN-SBA-SVN & $15500(200)$ & 3 & 80000 & $-37.78^{*}$ \\
\hline JUN-SBA-SVN & $15500(200)$ & 3 & 80000 & JUN-PBA-SVN & $20333(1102)$ & 3 & 2426667 & $-7.48^{*}$ \\
\hline JUN-PBA-SVN & 20333 (1102) & 3 & 2426667 & JUN-NBA-SVN & $7668(267)$ & 3 & 142617 & $19.22^{*}$ \\
\hline JUN-PBA-SVP & $935(70)$ & 3 & 9715 & OCT-PBA-SVP & 727 (89) & 3 & 15923 & $3.17^{*}$ \\
\hline JUN-SBA-SVP & $689(56)$ & 3 & 6301 & OCT-SBA-SVP & $285(9)$ & 3 & 171 & $12.32^{*}$ \\
\hline JUN-NBA-SVP & $344(47)$ & 3 & 4376 & OCT-NBA-SVP & $299(65)$ & 3 & 8467 & 0.97 \\
\hline OCT-PBA-CVP & 1503 (144) & 3 & 41667 & OCT-PBA-SVP & 727 (89) & 3 & 15923 & $7.92^{*}$ \\
\hline OCT-PBA-CVN & 8827 (498) & 3 & 496267 & OCT-PBA-SVN & $11100(985)$ & 3 & 1940000 & $-3.57^{*}$ \\
\hline OCT-NBA-SBM & $102(18)$ & 3 & 67 & OCT-SBA-SBM & $611(47)$ & 3 & 444 & $-17.43^{*}$ \\
\hline OCT-SBA-SBM & $611(47)$ & 3 & 444 & OCT-PBA-CBM & 1079 (38) & 3 & 282 & $-13.46^{*}$ \\
\hline OCT-PBA-CBM & 1079 (38) & 3 & 282 & OCT-NBA-SBM & 102 (18) & 3 & 67 & $40.53^{*}$ \\
\hline
\end{tabular}

* Statistically significant.

significantly higher within the peat-burned areas $(853 \pm$ $36 \mathrm{mg} / \mathrm{kg}$ ) than that in surface burned areas $(580 \pm$ $49 \mathrm{mg} / \mathrm{kg})$ and non-burned areas (398 $\pm 123 \mathrm{mg} / \mathrm{kg})$. Soil TP values in surface-burned area was higher than those in non-burned areas, but not statistically significant. These same trends were also noted for TP in surface water in that TP in peat-burned areas $(52 \pm 16 \mu \mathrm{g} / \mathrm{L})$ was significantly higher than that in surface-burned $(22 \pm$ $5 \mu \mathrm{g} / \mathrm{L})$ and non-burned $(18 \pm 4 \mu \mathrm{g} / \mathrm{L})$ areas. The same relative pattern appeared for porewater $\mathrm{TP}$, with values of $181 \pm 9,23 \pm 2$ and $20 \pm 2 \mu \mathrm{g} / \mathrm{L}$, for the peat-burned, surface-burned and non-burned areas, respectively. The post-fire porewater TP value in peat-burned areas was significantly higher than that in surface-burned $\left(t=28.96^{*}\right)$ and non-burned areas $\left(\mathrm{t}=29.51^{*}\right)$ (Table 1).

Significant differences $\left(t=-8.19^{*},-4.75^{*}\right.$, and $\left.12.19^{*}\right)$ of sawgrass TP values were noted in the non-burned, surface-burned and peat-burned areas with $344 \pm 47$, $689 \pm 56$, and $935 \pm 70 \mathrm{mg} / \mathrm{kg}$, respectively (Table 2). Sawgrass TN values in surface-burned areas $(15,500 \pm$ $200 \mathrm{mg} / \mathrm{kg}$ ) were approximately doubled $\left(\mathrm{t}=-37.78^{*}\right)$ to that of non-burned areas $(7,668 \pm 267 \mathrm{mg} / \mathrm{kg})$ with that in peat-burned areas $(20,333 \pm 1,102 \mathrm{mg} / \mathrm{kg})$ about twenty-five percent higher than that in surface-burned areas $\left(t=-7.48^{*}\right)$. Post fire sawgrass TP values in peatburned areas significantly dropped $\left(t=3.17^{*}\right)$ twenty-five percent from $935 \pm 70 \mathrm{mg} / \mathrm{kg}$ to $727 \pm 89 \mathrm{mg} / \mathrm{kg}$ between June 1 and October 5, 1999. There was also a significant $\left(\mathrm{t}=12.32^{*}\right)$ fifty percent drop of sawgrass TP values in surface-burned areas from $689 \pm 56 \mathrm{mg} / \mathrm{kg}$ on June 1 to $285 \pm 9 \mathrm{mg} / \mathrm{kg}$ on October 5 . There were no significant differences between sawgrass TP in non-burned areas in the period of June $1(344 \pm 47 \mathrm{mg} / \mathrm{kg})$ to October 5 $(299 \pm 65 \mathrm{mg} / \mathrm{kg}$ ) of 1999 (Figure 3). However, cattail TP $(1503 \pm 144 \mathrm{mg} / \mathrm{kg})$ collected on October 5, 1999 was twice $\left(t=7.92^{*}\right)$ that of sawgrass $(727 \pm 89 \mathrm{mg} / \mathrm{kg})$ collected at that same time (Table 2). Furthermore, there were significant differences $\left(t=-3.57^{* *}\right)$ between cattail TN $(8,827 \pm 498 \mathrm{mg} / \mathrm{kg})$ and sawgrass TN $(11,000 \pm$ $985 \mathrm{mg} / \mathrm{kg}$ ) in the peat-burned areas (Table 2).

This study also showed that post fire sawgrass regrowth $\left(611 \pm 47 \mathrm{~g} / \mathrm{m}^{2}\right)$ from June 1 to October 5 was approximately 5 times higher $\left(\mathrm{t}=-17.43^{*}\right)$ than sawgrass growing in non-burned stands $\left(102 \pm 18 \mathrm{~g} / \mathrm{m}^{2}\right)$ (Table 2). In another comparison, cattails $\left(1,079 \pm 38 \mathrm{~g} / \mathrm{m}^{2}\right)$ in peat-burned areas were growing approximately twice

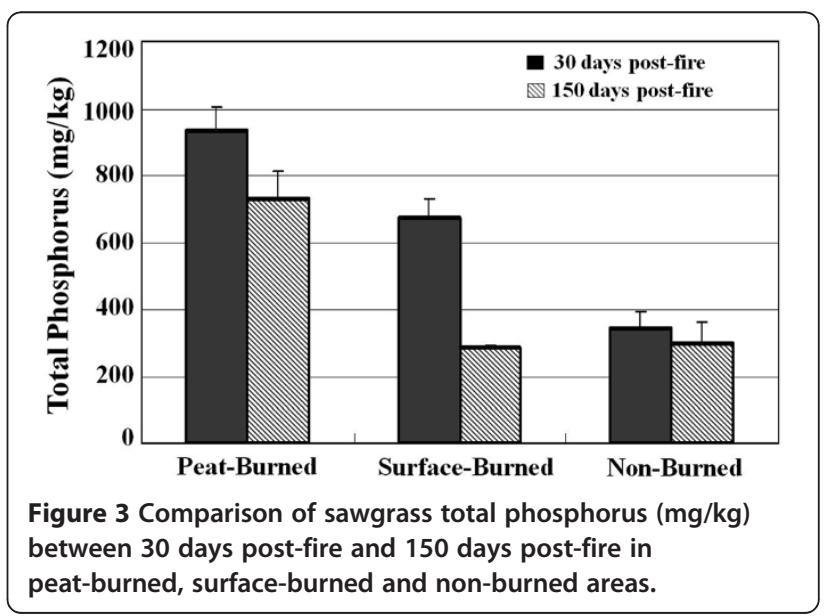


Table 3 t-Test of cattail coverage (CTC,\%) within sawgrass stand (SAW), sawgrass-cattail stand (SCT, cattails < $50 \%$ ), cattail-sawgrass stand (CTS, cattails $>\mathbf{5 0 \%}$ ) in surface-burned areas (SBA) and non-burned areas (NBA) based on 134 sampling sites, collected four years after 1999 fire, in May, 2003

\begin{tabular}{lcccccccc}
\hline X & Mean (s.d.) & $\mathrm{n}$ & $\Sigma(\mathrm{X}-\mathrm{M})^{2}$ & $\mathrm{Y}$ & Mean (s.d.) & $\mathrm{n}$ & $\Sigma(\mathrm{Y}-\mathrm{M})^{2}$ & $\mathrm{t}$ \\
\hline SBA-SAW-CTC & $8(7)$ & 30 & 1524 & NBA-SAW-CTC & $6(9)$ & 15 & 1023 & 0.77 \\
SBA-SCT-CTC & $49(21)$ & 25 & 10864 & NBA-SCT-CTC & $31(20)$ & 16 & 5711 & $2.71^{*}$ \\
SBA-CTS-CTC & $77(18)$ & 31 & 9869 & NBA-CTS-CTC & $61(20)$ & 17 & 6612 & $2.75^{*}$ \\
SBA-SAW-CTC & $8(7)$ & 30 & 1524 & SBA-SCT-CTC & $49(21)$ & 25 & 10864 & $-9.81^{*}$ \\
SBA-SCT-CTC & $49(21)$ & 25 & 10864 & SBA-CTS-CTC & $77(18)$ & 31 & 9869 & $-5.28^{*}$ \\
NBA-SAW-CTC & $6(9)$ & 15 & 1023 & NBA-SCT-CTC & $31(20)$ & 16 & 5711 & $-4.49^{*}$ \\
NBA-SCT-CTC & $31(20)$ & 16 & 5711 & NBA-CTS-CTC & $61(20)$ & 17 & 6612 & $-4.32^{*}$ \\
\hline
\end{tabular}

* Statistically significant.

$\left(\mathrm{t}=-13.46^{*}\right)$ as fast as sawgrass $\left(611 \pm 47 \mathrm{~g} / \mathrm{m}^{2}\right)$ in surface-burned areas. In terms of average daily growth rates in the period of June 1 to October 5 of 1999, sawgrass grew $0.8 \mathrm{~g} / \mathrm{m}^{2} /$ day in non-burned areas and $4.9 \mathrm{~g} / \mathrm{m}^{2} /$ day in surface-burned areas while cattail grew $8.6 \mathrm{~g} / \mathrm{m}^{2} /$ day in peat-burned areas. Post-fire water depths also showed an impact on sawgrass re-growth. Sawgrass re-growth in surface-burned areas reached $4.9 \pm 0.4 \mathrm{~g} /$ $\mathrm{m}^{2}$ /day in water depths less than $30 \mathrm{~cm}$ but decreased significantly $\left(t=6.44^{*}\right)$ to $0.5 \pm 0.3 \mathrm{~g} / \mathrm{m}^{2} /$ day in water depths greater than $60 \mathrm{~cm}$.

Survey results showed that post-fire community structures and cattail increase seemed to be influenced by initial presence of cattail, which meant that postfire community structures for sawgrass, sawgrass-cattail mix and cattail-sawgrass mix appeared to form differently depending on the amount of initial cattail found within each of these categories (Table 3). Figure 4 shows the percent distribution of cattail collected from those 134 sampling sites in May, 2003 (four years after the initial fire) for these categories in surface-burned and nonburned areas. Sawgrass areas that were void of cattail

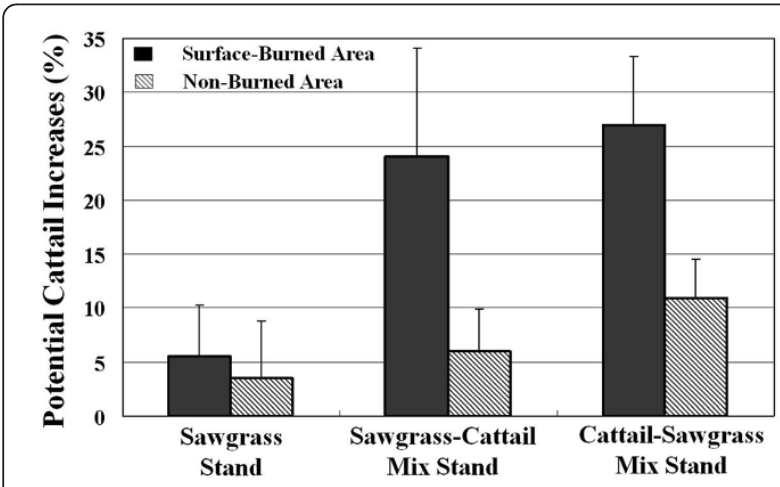

Figure 4 Potential cattail increases (\%) in different stands of sawgrass, sawgrass-cattail mix (cattails $<50 \%$ ) and cattailsawgrass mix (cattails $>50 \%$ ) stands between surface-burned and non-burned areas in WCA-3A, four years after the 1999 fire (1999-2003). before the 1999 fire were found to have very similar percentages of cattail for the surface-burned $(8 \pm 7 \%)$ and non-burned $(6 \pm 9 \%)$ areas four years after the fire (Table 3). In contrast, sawgrass-cattail mix and cattailsawgrass mix categories showed significant differences $\left(\mathrm{t}=2.71^{*}\right.$ and $\left.2.75^{*}\right)$ in percentage of cattail increases between surface-burned and non-burned areas. However, the amount of cattails was greater for the surface-burned (sawgrass-cattail mix: $49 \pm 21 \%$; cattail-sawgrass mix: 77 $\pm 18 \%$ ) areas as opposed to the non-burned areas (sawgrass-cattail mix: $31 \pm 20 \%$; cattail-sawgrass mix: $61 \pm$ $20 \%$ ) for these two categories (Table 3). These data show cattail increases of $2 \%, 18 \%$ and $16 \%$ coverage in surfaceburned sawgrass, sawgrass-cattail mix and cattailsawgrass mix categories, respectively compared to nonburned areas. These data also show that higher cattail increases in both surface-burned and non-burned areas depend on the amount of cattail initially present. Cattail growth in surface-burned areas of cattail-sawgrass mix stands $(77 \pm 18 \%)$ was significantly $(t=-5.28 \%)$ higher than in sawgrass-cattail mix stands $(49 \pm 21 \%)$, which again was significantly $\left(\mathrm{t}=9.81^{*}\right)$ higher than that of sawgrass stands $(8 \pm 7 \%)$. The same trend could be observed in non-burned areas with t-values of $-4.32 \%$ and $-4.49 \%$ (Table 3). Figure 4 shows that cattail increases in coverage were $5.5 \%, 24 \%$ and $27 \%$ in the surface-burned sawgrass, sawgrass-cattail mix and cattail-sawgrass mix categories, respectively, compared to $3.5 \%, 6 \%$ and $11 \%$ increases, respectively, in the non-burned areas four years after the 1999 fire. These data suggest that fire in cattail environments might facilitate cattail expansion.

This study suggested a strong positive relationship between cattail distribution and soil TP (Figure 5). Cattail distribution in six categories of soil TP concentration increased linearly from $8 \pm 4 \%$ cattail with $0-299 \mathrm{mg} / \mathrm{kg}$ of soil TP to $76 \pm 17 \%$ cattail with $>1100 \mathrm{mg} / \mathrm{kg}$ of soil TP in surface-burned areas (Table 4). The same trend could be seen in non-burned areas (Figure 5) with distribution of $4 \pm 5 \%$ cattail with $<300 \mathrm{mg} / \mathrm{kg}$ of soil TP to $70 \pm 15 \%$ cattail with $>1100 \mathrm{mg} / \mathrm{kg}$ of soil TP (Table 4 ). 


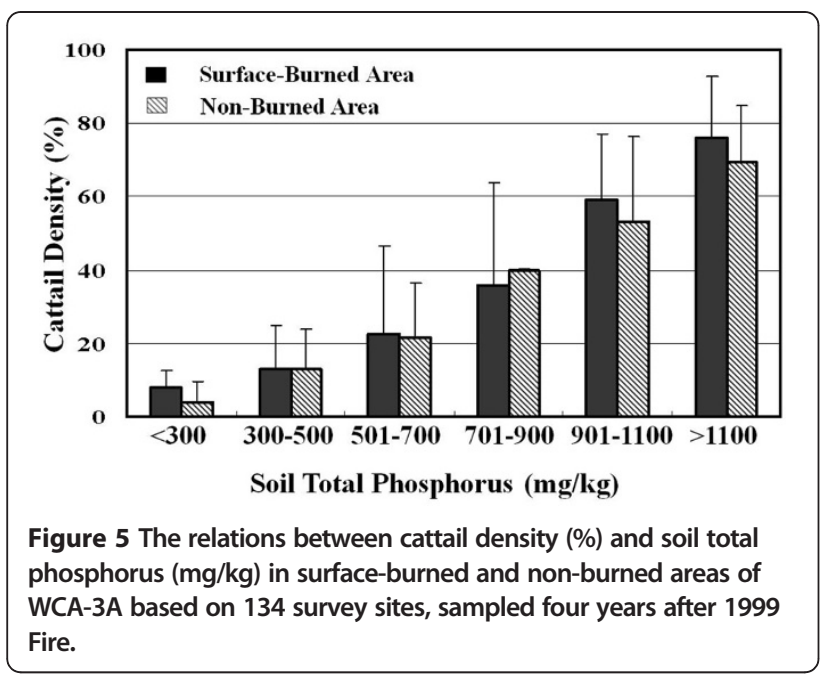

There were significant $\left(3.51^{*}\right.$ and $\left.-2.75^{*}\right)$ impacts of high soil TP on cattail expansion in surface-burned areas in the $900-1099 \mathrm{mg} / \mathrm{kg}$ and $>=1100 \mathrm{mg} / \mathrm{kg}$ of soil TP as opposed to cattail expansion in the $500-699 \mathrm{mg} / \mathrm{kg}$ and $700-899 \mathrm{mg} / \mathrm{kg}$ of soil TP, respectively. Similar significant $\left(-2.55^{*}\right.$ and $\left.-2.64^{*}\right)$ results were also found in the non-burned areas within those same ranges, but there was no significant difference between the surface-burned and non-burned areas (Table 4).

Figure 6 shows the mean TP concentrations of different soil layers $(0-2 \mathrm{~cm}$ and $2-10 \mathrm{~cm})$ and floc layers within cattail and sawgrass stands in non-burned areas. The mean TP concentration of the floc layer within cattail stands was $1080 \mathrm{mg} / \mathrm{kg}$, but only $400 \mathrm{mg} / \mathrm{kg}$ within

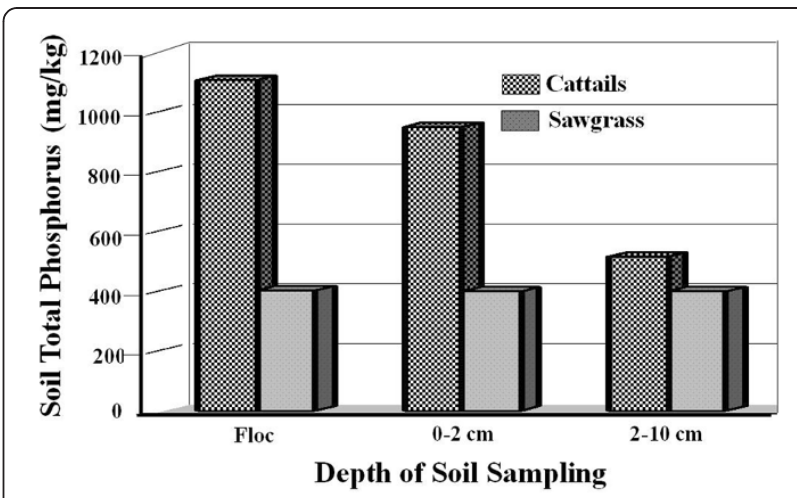

Figure 6 The correspondence of soil total phosphorus and the distribution of cattails and sawgrass in non-burned area.

sawgrass stands (Figure 6). Similar concentrations to floc were found in the $0-2 \mathrm{~cm}$ soil layer with mean TP concentrations in cattail and sawgrass stands of 930 and $390 \mathrm{mg} / \mathrm{kg}$, respectively. Mean TP concentrations in the $2-10 \mathrm{~cm}$ soil layer were not significantly different between cattail $(480 \mathrm{mg} / \mathrm{kg})$ and sawgrass $(390 \mathrm{mg} / \mathrm{kg})$ stands. Mean TP concentrations in all three layers (floc, $0-2 \mathrm{~cm}$ and $2-10 \mathrm{~cm}$ ) of sawgrass stands were roughly within the range of $390-400 \mathrm{mg} / \mathrm{kg}$ while higher levels of TP concentration were found in the floc and $0-2 \mathrm{~cm}$ soil layer within cattail stands.

\section{Discussion and conclusion}

This study suggests that there is initially (June 1) significantly higher TP in peat-burned and surface-burned areas than in non-burned areas after the 1999 fire in

Table $4 \mathrm{t}$-Test for cattail expansion (CTC\% increases) with different soil total phosphorus in both surface-burned area (SBA) and non-burned area (NBA) four years after the 1999 fire, sampling in May, 2003. Soil total phosphorus (mg/kg) categories: P01: 0-299; P02: 300-499; P03: 500-699; P04: 700-899; P05: 900-1099; P06: >= 1100

\begin{tabular}{|c|c|c|c|c|c|c|c|c|}
\hline$x$ & Mean (s.d.) & $\mathrm{n}$ & $\Sigma(\mathrm{X}-\mathrm{M})^{2}$ & $\mathrm{Y}$ & Mean (s.d.) & $\mathrm{n}$ & $\Sigma(\mathrm{Y}-\mathrm{M})^{2}$ & $\mathbf{t}$ \\
\hline SBA-P01-CTC & $8(4)$ & 5 & 80 & NBA-P01-CTC & $4(5)$ & 5 & 120 & 1.27 \\
\hline SBA-P02-CTC & $13(12)$ & 5 & 580 & NBA-P02-CTC & $13(10)$ & 5 & 480 & 0.00 \\
\hline SBA-P03CTC & $23(25)$ & 6 & 3088 & NBA-P03CTC & $22(15)$ & 6 & 1083 & 0.07 \\
\hline SBA-P04-CTC & $36(28)$ & 5 & 3120 & NBA-P04-CTC & $40(0)$ & 2 & 0 & -0.19 \\
\hline SBA-P05-CTC & $59(18)$ & 11 & 3241 & NBA-P05-CTC & $53(23)$ & 3 & 1067 & 0.47 \\
\hline SBA-P06-CTC & $76(17)$ & 5 & 1120 & NBA-P06-CTC & $70(15)$ & 11 & 2323 & 0.77 \\
\hline NBA-P01-CTC & $4(5)$ & 5 & 120 & NBA-P03CTC & $22(15)$ & 6 & 1083 & $-2.53^{*}$ \\
\hline NBA-P02-CTC & $13(10)$ & 5 & 480 & NBA-P04-CTC & $40(0)$ & 2 & 0 & $-3.29 *$ \\
\hline NBA-P03CTC & $22(15)$ & 6 & 1083 & NBA-P05-CTC & $53(23)$ & 3 & 1067 & $-2.55^{*}$ \\
\hline NBA-P04-CTC & $40(0)$ & 2 & 0 & NBA-P06-CTC & $70(15)$ & 11 & 2323 & $-2.64^{*}$ \\
\hline SBA-P01-CTC & $8(4)$ & 5 & 80 & SBA-P03CTC & $23(25)$ & 6 & 3088 & -1.28 \\
\hline SBA-P02-CTC & $13(12)$ & 5 & 580 & SBA-P04-CTC & $36(28)$ & 5 & 3120 & -1.69 \\
\hline SBA-P03CTC & $23(25)$ & 6 & 3088 & SBA-P05-CTC & $59(18)$ & 11 & 3241 & $-3.51^{*}$ \\
\hline SBA-P04-CTC & $36(28)$ & 5 & 3120 & SBA-P06-CTC & $76(17)$ & 5 & 1120 & $-2.75^{*}$ \\
\hline
\end{tabular}

* Statistically significant. 
northern WCA-3A. TP in surface-burned areas was noticeably higher than that in non-burned areas and, in comparison, $46 \%$ higher in soil, $22 \%$ in surface water, $15 \%$ in pore-water and $100 \%$ in sawgrass tissue. Soil, pore-water, surface water and sawgrass tissue. TP in peat-burned areas was $47 \%, 136 \%, 687 \%$ and $36 \%$ significantly higher than that in surface-burned areas, respectively. Bostic and White (2007) indicated that phosphorus enrichment of marsh soils can act as an internal source of nutrients to the water column and drive existing wetland eutrophic conditions. Steward and Ornes (1975) found a strong nutrient relationship in sawgrass re-growth after fire which differed considerably from sawgrass in non-burned areas. This current research also indicates that the amount of sawgrass TN was significantly higher in surface-burned $(15,500 \mathrm{mg} / \mathrm{kg})$ and peat-burned areas $(20,333 \mathrm{mg} / \mathrm{kg})$ than in non-burned areas $(7,668 \mathrm{mg} / \mathrm{kg})$. Gunderson and Snyder (1994) also spectulated that nutrients released as a result of fire appear to promote luxuriant plant re-growth and improve the overall marsh habitat.

This research is consistent with the hypothesis that fire, as an ecological process in the Everglades, facilitates nutrient release and subsequent plant re-growth (Miao et al. 2010). This conclusion is supported by a comparison of surface-burned sawgrass biomass $\left(611 \mathrm{~g} / \mathrm{m}^{2}\right)$ and average daily growth rate $\left(4.9 \mathrm{~g} / \mathrm{m}^{2}\right)$ to non-burned sawgrass biomass $\left(102 \mathrm{~g} / \mathrm{m}^{2}\right)$ and average daily growth rate $\left(0.8 \mathrm{~g} / \mathrm{m}^{2}\right)$. These post-fire cattail and sawgrass biomass accumulated values appear to correspond to the available TP concentrations found in the soil, pore-water and surface water within each of the non-burned, surfaceburned and peat-burned areas. Fire in the Everglades may continue to shape the marsh landscape and substrate composition and provide a mechanism whereby essential nutrients are released and whereby vegetation communities are maintained by the recycling of accumulated litter. Fire influenced in the evolution of the Everglades, and fire management must be understood in order to maintain the current natural ecosystem of the Everglades (Miao et al. 2010, Wu et al. 2002, 1996).

The data from this study suggest that TP released after a fire may not last more than 125 days within the environment. TP concentrations in sawgrass were reduced from $689 \mathrm{mg} / \mathrm{kg}$ (30 days post-fire) to $285 \mathrm{mg} / \mathrm{kg}$ (125 days post-fire) after the burn, which is not significantly different from the $299 \mathrm{mg} / \mathrm{kg}$ found in nonburned areas. Deep water $(>60 \mathrm{~cm}$ ) may also delay sawgrass re-growth (from 4.9 to $0.5 \mathrm{~g} / \mathrm{m}^{2} /$ day) following a fire. This supports Main and Barry's results (2002), for their results indicated that wet prairie grasses are promoted by early growing season fires, which cause an initial fast growth rate before the rainy season brings deeper water to the wetland. These data suggest that post-fire nutrient availability will initially enhance sawgrass regrowth, but high water levels could delay that growth. This study also supports Herndon et al.'s (1991) notion of water depth and fire shaping sawgrass community.

Fire may cause significant TP changes in peat-burned areas and impact cattails and sawgrass differently. Post peat-fire soil TP concentrations $(853 \mathrm{mg} / \mathrm{kg})$ were much higher than surface-burned areas $(580 \mathrm{mg} / \mathrm{kg})$. These post-peat-fire soil TP concentrations are also much higher than the $650 \mathrm{mg} / \mathrm{kg}$ threshold TP level that would promote and accelerate cattail expansion (Wu et al. 1997). The fast growth rate of cattails $\left(8.6 \mathrm{~g} / \mathrm{m}^{2} /\right.$ day $)$ after peatfires enabled them to outgrow the slower growing sawgrass $\left(4.9 \mathrm{~g} / \mathrm{m}^{2} /\right.$ day $)$. Cattail biomass $\left(1,079 \mathrm{~g} / \mathrm{m}^{2}\right)$ in 150-day post-peat-burn areas almost doubled that of sawgrass $\left(611 \mathrm{~g} / \mathrm{m}^{2}\right)$ in surface-burned areas and was ten times greater than that of sawgrass in non-burned areas $\left(102 \mathrm{~g} / \mathrm{m}^{2}\right)$. Comparisons of TP concentration in cattails $(1,503 \mathrm{mg} / \mathrm{kg})$ to that in sawgrass $(727 \mathrm{mg} / \mathrm{kg})$ provide further evidence that, under the right conditions, postfire, available TP releases may cause cattail expansion (Miao et al. 2001, Smith and Newman 2001).

This study also suggests that, under some situations, fire may provide undesirable effects within certain regions of the altered Everglades. Cattail increases in sawgrass stands were $5.5 \%$ in surface-burned areas vs. $3.5 \%$ in non-burned areas whereas sawgrass-cattail mix stands $(24 \%$ vs. $6 \%)$ and cattail-sawgrass mixed stands ( $27 \%$ vs. $11 \%)$ saw greater cattail invasion within the surface-burned than non-burned areas, respectively. These data indicate that post-fire cattail expansion is related to cattail stands existing before the fire. The data also suggest that cattails in the altered landscape grow in proportion to cattails after a surface-burn.

Smith et al. (2001) speculated that soil TP transformations may encourage the growth of invasive cattails. Similarly, this current study shows a positive relationship between cattail distribution and high soil TP. The survey data analyses show that cattail distribution in six categories of soil TP concentration of 0-299, 300-499, 500-699, 700$899,900-1099$, and $>1100 \mathrm{mg} / \mathrm{kg}$ was $8 \%, 13 \%, 23 \%, 36 \%$, $59 \%$, and $76 \%$, respectively in surface-burned areas. Cattails in the soil TP of 900-1099 and >=1100 mg/ $\mathrm{kg}$ have significantly higher cattail distributions than that in the soil TP of $500-699$ and $700-899 \mathrm{mg} / \mathrm{kg}$ in post-fire surface-burned environments. These data again are consistent with research suggested by Wu et al. (1997) that higher TP soil concentrations facilitate faster cattail expansion.

Soil sampling data from WCA-3A indicate that there are significantly higher concentrations of soil TP in cattail stands than in sawgrass stands; furthermore, cattails are more related to $\mathrm{TP}$ concentrations in the top layers of floc and 0-2 cm of soil. The TP of floc and 0-2 cm soil layer in cattail stands was $1,080 \mathrm{mg} / \mathrm{kg}$, and $930 \mathrm{mg} / \mathrm{kg}$, 
respectively, whereas it was $400 \mathrm{mg} / \mathrm{kg}$ vs. $390 \mathrm{mg} / \mathrm{kg}$, respectively, in sawgrass areas. TP in the $2-10 \mathrm{~cm}$ soil layer was not significantly different between cattail stands (480 mg/kg) and sawgrass stands (390 mg/kg), which indicates that the top soil layers (floc and 0-2 cm) contribute most of the phosphorus that allows cattail to expand and outgrow sawgrass. Wu et al. (1997) and Smith and Kadlec (1985) also showed that the effects of fire and TP on cattail expansion can be predicted. Behind both changes in cattail expansion (Rutchey et al. 2005) and increases in soil TP (Bruland et al. 2007), fire might be another force altering the Everglades.

In summary, although fire continues to be a positive metric for nutrient release and sawgrass re-growth, the data also suggest that fire within altered areas (e.g. high soil TP and/or high cattail density) of the Everglades could be more beneficial to cattails' growth and expansion than sawgrass. This conclusion holds especially true for peatfires, which may dramatically increase the expansion of cattails. This research further indicates that post-fire cattail expansion is related to original cattail distribution. The continued use of fire as a driving metric within the altered Everglades needs re-evaluation (LaPuma et al. 2007). This research indicates that ecologists and managers must redefine the role of fire as a natural process shaping the historical Everglades wetland, since fire may not act the same in all areas of an altered landscape.

\section{Competing interests}

The authors declare that they have no competing interests.

\section{Authors' contributions}

YW, SN, and FS participated in the post-fire survey and sampling. KR provided the GIS vegetation map and soil map. NW designed the GPS points of 134 sampling sites. SM provided the lab for sampling data measurement. WO carried out the soil and pore-water total phosphorus measurement. KR and FS made great efforts in editing the manuscript. All authors read and approved the final manuscript.

\section{Authors' information}

Ken Rutchey: ${ }^{* *}$ Retired from South Florida Water Management District.

\section{Acknowledgements}

This research resulted from the many discussions with our colleagues at the South Florida Water Management District and support from colleagues at Cardno ENTRIX.

\section{Author details}

${ }^{1}$ Everglades Division, South Florida Water Management District, 3301 Gun Club Road, West Palm Beach, FL 33406, USA. ².S. Geological Survey, MS 956, 12201 Sunrise Valley Drive, Reston, VA 20192, USA. ${ }^{3}$ Cardno ENTRIX, 339 Whitecrest Drive, Maryville, TN 37801, USA.

\section{Received: 7 June 2012 Accepted: 14 August 2012}

Published: 11 October 2012

\section{References}

Adorisio C, Bedregal C, Daroub S, DeLeon J, Edwards M, Garvey C, Madden J, McGinnes P, Miessau C, Pescatore D, Sievers P, Van Horn S, van Veen T, Vega J, Xue S, Zhao H (2006) Phosphorus controls for the Basins Tributary to the Everglades Protection Area. In: 2006 South Florida Environmental Report, Chapter 3. South Florida Water Management District, West Palm Beach, Florida, pp 1-89
Alder HL, Roessler EB (1972) Introduction to probability and statistics, Fifthth edn. W.H. Freeman and Company, San Francisco, p 373

Anderson RC (2006) Evolution and origin of the Central Grassland of North America: climate, fire, and mammalian grazers. The Journal of the Torrey Botanical Society 133(4):626-647

Arabas KB (2000) Spatial and temporal relationships among fire frequency, vegetation, and soil depth in an eastern North American serpentine barren. The Journal of the Torrey Botanical Society 127(1):51-65

Beckage B (2005) Response to Maehr and Larkin natural fire regimes in southern Florida. Natural Areas Journal 25(1):6-8

Beckage B, Platt WJ (2003) Predicting severe wildfires years in the Florida Everglades. Frontier in Ecology and the Environment 1(3):235-239

Beckage B, Platt WJ, Pank B (2005) A climate-based approach to the restoration of fire-dependent ecosystems. Restor Ecol 13(3):429-431

Beckage B, Platt WJ, Gross LJ (2009) Vegetation, fire and feedbacks: a disturbance-mediated model of savannas. Am Nat 174(6):805-818

Bostic EM, White JR (2007) Soil phosphorus and vegetation influence on wetland phosphorus release after simulated drought. Soil Sci Soc Am J 71:238-244

Bruland GL, Osborne TZ, Reddy KR, Grunwald S, Newman S, DeBusk WF (2007) Recent changes in soil total phosphorus in the everglades: water conservation area 3. Environ Monit Assess 129(1-3):379-395

Certini G (2005) Effects of fire on properties of forest soils. Oecologia 143(1):1-10

Childers DL, Boyer JN, Davis SE, Madden CJ, Rudnick DT, Sklar FH (2006) Nutrient concentration patterns in the oligotrophic "upside-down" estuaries of the Florida Everglades. Limnol Oceanogr 51(1):602-616

Dash RM, Frith ML (2011) Some observations on the effect of different drying methods on the glycoside content of the leaves of Digitalis lanata. J Pharm Pharmacol 6(1):471-475

Davis SM (1991) Growth, decomposition, and nutrient retention of Cladium jamaicense Crantz and Typha domingensis Pers. In the Florida Everglades. Aquat Bot 40:203-224

Davis SM (1994) Phosphorus inputs and vegetation sensitivity in the Everglades. In: Davis SM, Ogden JC (eds) Everglades: The Ecosystem and its Restoration. Lucie Press, Boca Raton, FL (USA), St, pp 357-378

DeBusk WF, Newman S, Reddy KR (2001) Spatio-temporal patterns of soil phosphorus enrichment in Everglades Water Conservation Area 2A. J Environ Qual 30:1438-1446

Doren RF, Armentano TV, Whiteaker LD, Jones RD (1997) Marsh vegetation patterns and soil phosphorus gradients in the Everglades ecosystem. Aquat Bot 56(199): 145-163

Gilliam FK, Platt WJ (2006) Conservation and restoration of the Pinus palustris ecosystem. Appl Veg Sci 9(1):7-10

Gu B, Miao S, Edelstein C, Dreschel T (2008) Effects of a prescribed fire on dissolved inorganic carbon dynamics in a nutrient-enriched Everglades wetland. Fundam Appl Limnol 171(4):263-272

Gunderson LH (1994) Vegetation of the Everglades: determinants of community composition. In: Davis SM, Ogden JC (eds) Everglades, the Ecosystem and its Restoration. Lucie Press, Boca Raton, FL (USA), St, pp 323-340

Gunderson LH, Snyder JR (1994) Fire patterns in the southern Everglades. In: Davis SM, Ogden JC (eds) Everglades, the ecosystem and its restoration. Lucie Press, Boca Raton, pp 291-305

Hagerthey SE, Newman S, Rutchey K, Smith EP, Godin J (2008) Multiple regime shifts in a subtropical peatland: community-specific thresholds to eutrophication. Ecol Monogr 78(4):547-565

Herndon A, Gunderson L, Stenberg J (1991) Sawgrass (Cladium jamaicense) survival in a regime of fire and flooding. Wetlands 11(1):17-27

Ilstedt U, Nordgren A, Malmer A (2006) Soil chemical and microbial properties after disturbance by crawler tractors in a Malaysian forest plantation. For Ecol Manage 225(1-3):313-319

Imbert D, Delbé $L$ (2006) Ecology of fire-influenced Cladium jamaicense marshes in Guadeloupe, Lesser Antilles. Wetlands 26(2):289-297

LaPuma DA, Lockwood JL, Davis MJ (2007) Endangered species management requires a new look at the benefit of fire: The Cape Sable seaside sparrow in the Everglades ecosystem. Biol Conserv 136(3):398-407

Lockwood JL, Ross MS, Sah JP (2003) Smoke on the water: the interplay of fire and water flow on Everglades restoration. Front Ecol Environ 1(9):462-468

Main MB, Barry MJ (2002) Influence of Season of Fire on Flowering of Wet Prairie Grasses in South Florida, USA. Wetlands 22(2):430-434

Miao S, DeBusk WF (1999) Effects of phosphorus enrichment on structure and function of sawgrass and cattail communities in Florida Everglades. In: Reddy 
KR (ed) Phosphorus biogeochemistry in subtropical ecosystems. CRC Press, Lewis Publishers, pp 275-299

Miao S, McCormick PV, Newman S, Rajagopalan S (2001) Interactive effects of seed availability, water depth, and phosphorus enrichment on cattail. Wetl Ecol Manag 9(1):39-47

Miao S, Edelstein C, Carstenn S, Gu B (2010) Immediate ecological impacts of a prescribed fire on a cattail-dominated wetland in Florida Everglades. Fundamental and Applied Limnology. Arch Hydrobiol 176(1):29-41

Nelson TA, Robertson C (2012) Refining spatial neighbourhoods to capture terrain effects. Ecol Process 2012 1:3

Newman S, Grace JB, Koebel JW (1996) Effects on nutrients and hydroperiod on Typha, Cladium, and Eleocharis: implications for Everglades restoration. Ecol Appl 6(3):774-83

Newman S, Reddy KR, DeBusk WF, Wang Y, Shih G, Fisher M (1997) Spatial distribution of soil nutrients in a northern Everglades marsh. Water Conservation Area 1. Soil Science Society of American Journal 61(4):1275-1283

Newman S, Schuette J, Grace JB, Rutchey K, Fontaine T, Reddy KR, Pietrucha M (1998) Factors influencing cattail abundance in the northern Everglades. Aquat Bot 60(3):265-280

Ogden JC (2005) Everglades ridge and slough conceptual ecological model. Wetlands 25(4):810-820

Rashid GH (1987) Effects of fire on soil carbon and nitrogen in a Mediterranean oak forest of Algeria. Plant Soil 103(1):89-93

Reddy KR, Wang Y, DeBusk WF, Newman S (1994) Physico-chemical properties of the soils in the water conservation area 3 (WCA-3) of the Everglades. Report submitted to SFWMD, contract \# C90-1168

Ross MS, Mitchell-Bruker S, Sah JP, Stothoff S, Ruiz LP, Reed DL, Jayachandran K, Coultas CL (2006) Interaction of hydrology and nutrient limitation in the Ridge and Slough landscape of the southern Everglades. Hydrobiologia 569(1):37-59

Rutchey K, Vilchek L (1999) Air photo-interpretation and satellite imagery analysis techniques for mapping cattail coverage in a northern Everglades impoundment. Photogramm Eng Remote Sens 65(2):185-191

Rutchey K, Vilchek L, Love M (2005) Development of a vegetation map for Water Conservation Area 3. Technical Publication ERA \#421, South Florida Water Management District. West Palm Beach, Florida

Scheidt DJ, Kalla PJ (2007) Everglades ecosystem assessment: water management and quality, eutrophication, mercury contamination, soils and habitat: monitoring for adaptive management: a R-EMAP status report. USEPA Region 4, Athens, GA, EPA 904-R-07-001. 98 pp

Slocum MG, Platt WJ, Cooley HC (2003) Effects of differences in prescribed fire regimes on patchiness and intensity of fires in subtropical savannas of Everglades National Park, Florida. Restor Ecol 11(1):91-102

Smith LM, Kadlec JA (1985) Predictions of vegetation change following fire in a Great Salt Lake marsh. Aquat Bot 21(1):43-51

Smith SM, Newman S (2001) Growth of Southern Cattail (Typha domingensis Pers.) seedlings in response to fire-related soil Transformations in the northern Florida Everglades. Wetlands 21(3):363-369

Smith SM, Newman S, Garrett PB, Leeds JA (2001) Differential effects of surface and peat fire on soil constituents in a degraded wetland of the northern Florida Everglades. J Environ Qual 30:1998-2005

Steward KK, Ornes WH (1975) The autecology of sawgrass in the Florida Everglades. Ecology 56(1):162-171

Vogl RJ (1973) Effects of fire on the plants and animals of a Florida wetland. Am Midl Nat 89(2):334-347

Wade DD, Ewell J, Hofstetter R (1980) Fire in south Florida ecosystems. Gen. Tech. Rep. SE-17. U.S. Department of Agriculture, Forest Service. Southeastern Forest Experiment Station, Asheville, NC, p 125

Wu Y, Sklar FH, Gopu K, Rutchey K (1996) Fire simulations in the Everglades landscape using parallel programming. Ecol Model 93:113-124

Wu Y, Sklar FH, Rutchey K (1997) Analysis and simulations of fragmentation patterns in the Everglades. Ecol Appl 7(1):268-276

Wu Y, Rutchey K, Guan W, Vilchek L, Sklar FH (2002) Spatial simulations of tree islands for Everglades restoration. In: van der Valk A, Sklar FH (eds) Tree islands of the Everglades. Kluwer Academic Publishers, Dordrecht, The Netherlands, pp 469-499

Wu Y, Rutchey K, Wang N (2006) An analysis of spatial complexity of ridge and slough patterns in the Everglades ecosystem. Ecol Complex 3(3):183-192
Young DR, Brantley ST, Naumann JC, Vick JK (2011) Landscape position and habitat polygons in a dynamic coastal barrier environment. Ecosphere 2(6): Article 71

doi:10.1186/2192-1709-1-8

Cite this article as: Wu et al.: Impacts of fire and phosphorus on sawgrass and cattails in an altered landscape of the Florida Everglades. Ecological Processes 2012 1:8.

\section{Submit your manuscript to a SpringerOpen ${ }^{\circ}$ journal and benefit from:}

- Convenient online submission

- Rigorous peer review

- Immediate publication on acceptance

- Open access: articles freely available online

- High visibility within the field

- Retaining the copyright to your article

Submit your next manuscript at $\gg$ springeropen.com 